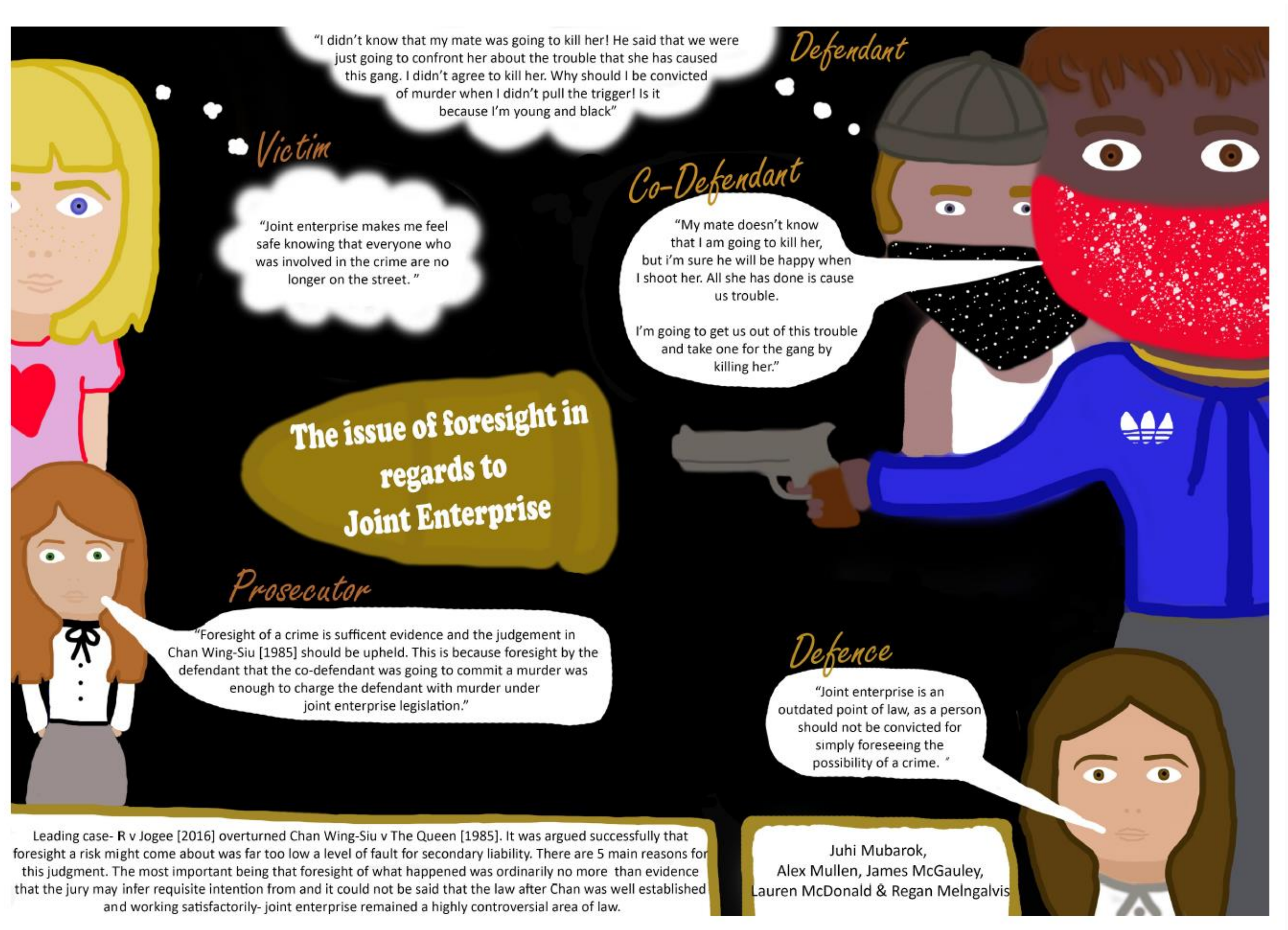




\section{Why did the Supreme Court rule that the issue of foresight had been misinterpreted for the past 30 years with regards to joint enterprise?}

\section{Introduction}

Joint enterprise is an area of law that has no statutory definition; instead being developed through the common law. It involves situations where more than one defendant can be convicted of the same crime, even if the co-defendant did not play an active role in the crime and, since it is common law based, many would argue (including Ben Crewe, a scholar) that the laws surrounding it have been created in a 'hazardous way'. ${ }^{1}$ This has ultimately resulted in the Supreme Court ruling in 2016 that the law had been misinterpreted for the past 30 yearsand judges had been using the law to wrongfully convict people ${ }^{2}$, with a major factor being the issue of foresight had been misunderstood. In the past the jury had been able to use proof of foresight of a crime as a suitable mens rea for joint enterprise, a lower mens rea threshold than for other convictions of murder ${ }^{3}$ and post 2016 this is no longer the case. This essay will therefore explore the leading case where the decision to overturn the law was made, what happened prior to 2016 and any appeal cases and the social context of joint enterprise legislation.

\section{Leading Case}

In 2016, the law surrounding joint enterprise was turned on its head when the Supreme Court, in the case of $\mathrm{R} v$ Jogee (Ameen Hassan) ${ }^{4}$, was asked to review the doctrine of parasitic accessory liability that had been laid down by the Privy Council 30 years earlier in the case of Chan Wing-Siu v The Queen ${ }^{5}$. Ultimately, the Court decided it could not support the Chan Wing-Siu principle, since the introduction of the principle was based on "an incomplete, and in some respects erroneous, reading of the previous case law, coupled with generalised and questionable policy arguments”6 - a decision that would likely have big consequences for past and future rulings in the area of joint enterprise alike.

\footnotetext{
${ }^{1}$ Ben Crewe et al 'Joint enterprise: the implications of an unfair and unclear law' (2015) Issue 4 Criminal law Review 252

${ }^{2} R v$ Jogee (Ameen Hassan) [2016] UKSC 8; [2017] AC 387

${ }^{3}$ Ibid

${ }^{4}$ [2016] UKSC 8; [2017] AC 387

${ }^{5}$ [1985] 1 AC 168

${ }^{6} R$ v Jogee (Ameen Hassan) [2016] UKSC 8; [2017] AC 387
} 
In the case it was alleged by the prosecution that the defendant had participated in joint enterprise with his co-defendant to commit an act which resulted in the victim's death. ${ }^{7}$ The judge advised the jury that the defendant was guilty of murder if he had participated in the attack and "realised" that his co-defendant might stab the victim with intent to cause him "really serious harm". 8 The defendant was found guilty and sentenced to life imprisonment, with the Court of Appeal later dismissing the defendant's appeal against conviction. The defendant appealed to the Supreme Court on the grounds that the judge's directions to the jury on joint enterprise were incorrect and that the case law, which was binding on trial judges in regard to the directions given to the jury, needed to be reviewed. It was argued that foresight that a risk might come about was far too low a level of fault for secondary liability. ${ }^{9}$ The appeal was allowed as it was stated that the Chan Wing-Siu principle could not be supported and the judgement was overturned.

Although reversing a statement of principle, which had been made and followed by the Privy Council and House of Lords on numerous occasions over many years, was undoubtedly a big (and rare) step, it was the right decision for several reasons. The first of these is that the court, in 2016, arguably had the benefit of a 'much deeper and extensive analysis of the topic of socalled "joint enterprise" liability than on previous occasions when the topic was considered." ${ }^{10}$ When reviewing the authorities, there is now little doubt that the Privy Council laid down a new principle in Chan when it held that if two people set out to commit an offence (crime A), and in the course of it one of them commits another offence (crime B), the second person is guilty as an accessory to crime $\mathrm{B}$ if he foresaw it as a possibility, but did not necessarily intend it. ${ }^{11}$ Some of the authorities the Privy Council relied upon in laying down this principle was Davies v DPP ${ }^{12}$ and R v Anderson; R v Morris ${ }^{13}$. In R v Anderson; R v Morris the Court of Appeal affirmed $\mathrm{R} v$ Smith (Wesley) ${ }^{14}$ including the rule that "if an adventurer departed completely from what had been tacitly agreed as part of an agreed joined enterprise then his co-adventurer would not be liable for the consequences of the unauthorised act. In such a situation the effect of the overwhelming supervening act is that any assistance is spent." ${ }^{15}$ The

\footnotetext{
${ }^{7} R v$ Jogee (Ameen Hassan) [2013] EWCA Crim 1433, [2013] 7 WLUK 365

${ }^{8} R v$ Jogee (Ameen Hassan) [2016] UKSC 8; [2017] AC 387

${ }^{9}$ Ibid

${ }^{10}$ Ibid [61]

${ }^{11}$ Ibid [62]

12 [1954] AC 378; [1954] 2 WLR 343

${ }^{13}$ [1966] 2 QB 110; [1966] 2 WLR 1195

${ }^{14}$ [1963] 1 WLR 1200; [1963] 3 All ER 597

${ }^{15} R$ v Anderson (Lascelles Fitzalbert) [1966] 2 QB 110; [1966] 2 WLR 1195
} 
Court did not otherwise address the question of what is necessary to establish joint responsibility, and specifically what is required is intention to assist or mere foresight of what D1 might do. Still less did it address the meaning of foresight or authorisation, so it provided no foundation to the rule in Chan. ${ }^{16}$ Also, as pointed out by Lord Brown of Eaton-underHeywood in R v Rahman (Islamur) ${ }^{17}$ "the rule in Chan makes guilty those who foresee crime B but never intended it/ wanted it to happen. Although there can be no doubt that if D2 continues to participate in crime A with foresight that D1 may commit crime B, that is evidence, and sometimes powerful evidence, of an intent to assist D1 in crime B. But it is evidence of such intent, not conclusive of it." 18 Additionally, a second reason for this change in direction can be argued to be due to the fact that it could not be said that the law was now well established and working satisfactorily; joint enterprise had remained a highly controversial area of law and a continuing source of difficulty for trial judges. ${ }^{19}$ It has hence led to a number of appeals, some of which will be mentioned later on in this essay. Furthermore, a third reason why it was decided that a change to the law was necessary was that, since secondary liability was an important part of the common law, if the judges felt that a wrong turn had been taken it should be corrected. ${ }^{20}$ In the language of criminal law 'a person who assists or encourages another to commit a crime is known as an accessory/secondary party, with the actual perpetrator known as a principal. It is a fundamental principle of criminal law that the accessory is guilty of the same offence as the principle- he shares the same physical act because even if it was not his hand that struck the blow, he has encouraged or assisted the physical act. These principals are well established and uncontroversial. ${ }^{21}$ It is only within the last 20 years that a new term, "parasitic accessory liability" has entered the realm of criminal lawyers, first coined by Professor Sir John Smith in 1997 to describe the doctrine laid down in Chan and developed in later cases, including most importantly, in the decision of the House of Lords in R v Powell (Anthony Glassford); R v English ${ }^{22} .{ }^{23}$ Therefore, as to the argument that, even if the court was satisfied that the law took the wrong turn, any correction should now be left to Parliament, the doctrine of secondary liability is a common law doctrine and, if it has been unduly widened by the courts, it was proper for the courts to correct the error. ${ }^{24}$ Another reason for this change is

\footnotetext{
${ }^{16} R$ v Jogee (Ameen Hassan) [2016] UKSC 8; [2017] AC 387 [64]

17 [2008] UKHL 45; [2009] 1 AC 129 [63]

${ }^{18} R$ v Jogee (Ameen Hassan) [2016] UKSC 8; [2017] AC 387 [66]

${ }^{19}$ Ibid [81]

${ }^{20}$ Ibid [82]

${ }^{21}$ Ibid [1]

22 [1999] 1 AC 1; [1997] 3 WLR 959

${ }^{23} R$ v Jogee (Ameen Hassan) [2016] UKSC 8; [2017] AC 387 [2]

${ }^{24}$ Ibid [85]
} 
that, in the common law, 'foresight' of what happened was ordinarily no more than evidence that the jury may infer requisite intention from. It might be strong evidence but its adoption as a test for the mental element of murder in the case of a secondary party was a 'serious and anomalous' departure from the basic rule resulting in an overextension of the law of murder and a reduction of the law of manslaughter. ${ }^{25}$ Murder already has a relatively low mens rea threshold (only an intention to cause serious injury) and the Chan principle extended liability for murder to a secondary party on the basis of an even lesser degree of culpability (foresight of the possibility that the principle might commit murder, with no need for an intention to assist him). ${ }^{26}$ Finally, the rule had a striking anomaly of requiring a lower mental threshold for guilt in the case of the accessory than the principal, the cases of Chan and Powell superseded. ${ }^{27}$ Therefore the Supreme Court correctly decided that the proper course of action was to restate the principles that had been established over the course of many years before the court took a wrong turn in Chan. The error was 'to equate foresight with the intent to assist, as a matter of law; the correct approach is to treat foresight as evidence of intent ${ }^{28}$ and nothing more.

\section{Before and After 1985}

One of the most famous cases involving joint enterprise before the Chan ruling was a case surrounding a burglary in 1953. Within this case, the police arrived at the scene and restrained both Derek Bentley ${ }^{29}$ and Christopher Craig; asking Craig to hand over the gun he was in possession of. Once PC Sydney Miles asked this, Bentley shouted out the ambiguous phrase "let him have it", which was overheard by three other policemen at the scene and this evidence was given in court as a means of encouragement and hence the basis of the court's judgement when deciding joint enterprise. The role of foresight within this case was Bentley not only knowing that there was going to be a crime committed, but also inciting Craig to shoot the policeman by using that phrase.

A more modern case (after the Chan judgement) involves Jordan Cunliffe ${ }^{30}$ who was convicted alongside others of the murder of Gary Newlove and sentenced to a minimum of 12 years in prison. Due to this being gang related, and that he had already caused damage and behaved aggressively, these were both aggravating factors within the law. He watched and took part in

\footnotetext{
${ }^{25} R$ v Jogee (Ameen Hassan) [2016] UKSC 8; [2017] AC 387 [83]

${ }^{26}$ Ibid

${ }^{27}$ Ibid [84]

${ }^{28}$ Ibid [87]

${ }^{29} R v$ Bentley (Deceased) [1998] 7 WLUK 610

${ }^{30} R$ v Cunliffe (Jordan) [2010] EWCA crim 2483
} 
the beating up of the victim, therefore this was the role of foresight as he knew there was a risk of serious injury and did nothing to avoid it. Although, this has been seen as controversial as it was witnessed by Cunliffe, he did not deliver the fatal kick, however the courts saw it fitting to convict him of murder.

R v Smith ${ }^{31}$ is a case, shortly after the Chan ruling, concerning grievous bodily harm, where both people agreed to do some harm, but not serious harm. However, the other defendant changed his mind and decided to inflict really serious bodily harm on the victim. Due to joint enterprise, Smith was also convicted of causing grievous bodily harm with intent. It was decided in court that Smith had 'foreseen' that his partner might have attacked him viciously and did nothing to prevent this. It was found to be highly controversial as he should not have been convicted of the crime another committed just because he was there to witness it. These cases, along with many others, were vital in the decision made by the Supreme Court around the issue of foresight being misinterpreted.

\section{Appeals}

As for where the law currently stands and how judges examine who was wrongfully convicted, the new law states that the correct approach should have been to treat foresight as evidence rather than assuming that it was intent, but what about those who have been wrongfully convicted? The case of $\mathrm{R} v$ Johnson gives us a much clearer understanding of how the new law works and how judges decide on new appeals. R v Johnson ${ }^{32}$ reveals "Section 2(2) (of the Criminal Appeal Act 1868) emphasised that...the court should only allow the appeal if it thought that the conviction was unsafe" 33 . The meaning of unsafe in this context is "a legal decision that someone is guilty may be wrong because it is based on bad evidence" 34 .

R v Johnson emphasises that for an appeal to be upheld, a "substantial injustice" must have been done. This corroborates R v Jogee which states that "Courts have the power to grant such leave, and may do so if substantial injustice be demonstrated, but it will not do so simply because the law applied has now been declared to have been mistaken”35. This hence reveals why there have been very few appeal cases, as even if convicted under an incorrect law, your appeal will not succeed unless there was substantial injustice. The courts expand on this during

\footnotetext{
${ }^{31} R$ v Smith [1988] 4 WLUK 131

32 [2016] EWCA Crim 1613

${ }^{33}$ Ibid

34 'Unsafe' Cambridge Dictionary <https://dictionary.cambridge.org/dictionary/english/unsafe>

${ }^{35} R$ v Jogee (Ameen Hassan) [2016] UKSC 8; [2017] AC 387 [100]
} 
the case of R v Burton, ${ }^{36}$ stating that "it was not appropriate to reduce an otherwise appropriate minimum term because a co-accused might have been treated leniently, unless the difference in sentencing would cause right-thinking members of the public to consider that the offender had a justified sense of grievance.”. In short, this means an appeal would only be appropriate if the general public thought the offender had been handed a grossly unjust sentence.

Of the appeals that have taken place, the majority have been dismissed by the courts including the aforementioned $\mathrm{R} v$ Johnson ${ }^{37}$ and $\mathrm{R} v$ Burton ${ }^{38}$ as the courts believed there had been no substantial injustice. However, one of the few appeals that have been successful was that of $\mathrm{R}$ $\mathrm{v}$ Crilly ${ }^{39}$. Crilly was convicted of murder when he and his friends broke into the flat of a 71 year old man who they believed to be out of the flat. In reality, the victim was in the flat but could not hear the doorbell due to a hearing impairment. When Crilly found that there was a man inside, he insisted that he and his friends leave the flat and he went outside whereas his friends stayed to rob the victim and then punched him in the face which caused his death. The courts allowed his appeal on the premise that if it was denied then substantial injustice would have been caused as the foresight that Crilly may have had did not equate to intent as he was not aware the victim was in the flat beforehand.

\section{Social Context}

As for the social context of joint enterprise, it was found that few media sources such as newspapers and documentaries, have focused on the misinterpretation of foresight, the majority of sources predominantly focusing on the negative impact of joint enterprise within the law by looking at the offender's perspective. Many newspapers believe 'that the law has been used to target young people from black, Asian and minority ethnic backgrounds by associating them unjustifiably with 'gangs'. ${ }^{40}$ An academic from Manchester Metropolitan University conducted a survey which showed that ' 87 percent of those on the Metropolitan Police 'gang matrix' (Trident) were black and minority ethnic...half of those convicted of serious youth violence were black and minority ethnic people ${ }^{, 41}$. This reinforces the argument that joint

\footnotetext{
36 [2017] EWCA Crim 107; [2017] 1 WLUK 446;

37 [2016] EWCA Crim 1613

38 [2017] EWCA Crim 107; [2017] 1 WLUK 466;

39 [2018] EWCA Crim 168

${ }^{40}$ Owen Bowcott, 'Senior Tories urge government to review joint enterprise laws' The Guardian (25 January 2018)

${ }^{41}$ Patrick Williams and Becky Clark, ‘Are joint enterprise convictions racially motivated?’ (2016) 1 (1) MMU

$<$ https://www2.mmu.ac.uk/news-and-events/news/story/?id=4088> accessed 21 November 2018
} 
enterprise is; 'the lazy prosecutor's dream' 42 as it can be used by judges as a tool to remove all potential offenders even if they did not participate substantially. However, this is controversial as many gangs (potential offenders) happen to be of an ethnic background, which has given the public a bad perception of the law on joint enterprise (explaining why many media sources have written about the bad implications of joint enterprise only).

Nevertheless, away from the negative portrayal of joint enterprise, one particular media source did discuss why joint enterprise is beneficial to society. For instance for 'young women that have been so traumatised or drugged that they are unable to provide an account of exactly which suspect did what to them during a sexual assault but their testimony, and other corroborating evidence, can demonstrate that a number of people were involved. ${ }^{43}$ Here, the need for joint enterprise is definitely essential from the victim's perspective as this allows the victim to feel safe and reassured that all potential offenders have been convicted. This source was unusual however in that it looked at the victim's perspective and why they believe that joint enterprise is necessary- this could be because many believe that using joint enterprise as a tool to convict black and ethnic minority gangs outweighs the victim's perspective. Therefore, it is clear to say that joint enterprise is a highly controversial topic within the media and will likely remain so due to the conflicting perspectives of the offender and the victim.

\section{Conclusion}

To conclude the Courts had been misinterpreting joint enterprise for the last 30 years. The courts showed the reason for this in $\mathrm{R} v$ Jogee, however despite this there have been very few successful appeals. More research would need to be untaken in order to conclude that a true bias exists for males for minority backgrounds, for these types of convictions.

\footnotetext{
${ }^{42}$ Sandra Paul, 'why joint enterprise is unfair and needs changing' (Law Society Gazette, 23 December 2014)

${ }^{43}$ Carlene Firmin, 'Joint enterprise law seem to unfairly target young people' The Guardian, (22 July 2014) 


\section{Bibliography}

\section{Primary Sources}

\section{$\underline{\text { Cases }}$}

Chan Wing-Siu v The Queen [1985] 1 AC 168

Davies v DPP [1954] AC 378; [1954] 2 WLR 343

R v Anderson (Lascelles Fitzalbert) [1966] 2 QB 110; [1966] 2 WLR 1195

R v Bentley (Deceased) [1998] 7 WLUK 610

R v Burton [2017] EWCA Crim 107; [2017] 1 WLUK 446

R v Crilly [2018] EWCA Crim 168

R v Cunliffe (Jordan) [2010] EWCA Crim 2483

R v Dobson (Gary); R v Norris (David) [2012] 1 WLUK 5

R v Jogee (Ameen Hassan) [2013] EWCA Crim 1433, [2013] 7 WLUK 365

R v Jogee (Ameen Hassan) [2016] UKSC 8; [2017] AC 387

R v Johnson [2016] EWCA Crim 1613

R v Powell (Anthony Glassford); R v English [1999] 1 AC 1; [1997] 3 WLR 959

R v Rahman (Islamur) [2008] UKHL 45; [2009] 1 AC 129 [63] 


\section{Secondary Sources}

$\underline{\text { Newspaper articles }}$

Bowcott, O. (2018). Senior Tories urge government to review joint enterprise laws. The Guardian. [online] Available at: <https://www.theguardian.com/law/2018/jan/25/seniortories-urge-government-to-review-joint-enterprise-laws> Accessed 5 Nov. 2018

Firmin, C. (2014). Joint enterprise law seem to unfairly target young people. The Guardian, [online] p.single page. Available at: <https://www.theguardian.com/society/2014/jul/22/jointenterprise-law-targeting-young-people> Accessed 5 Nov. 2018

$\underline{\text { Online Journals }}$

Crewe, B. et al 'Joint enterprise: the implications of an unfair and unclear law' (2015) Issue 4 Criminal law Review 252

Paul, S. (2014). Why joint enterprise is unfair and needs changing. [online] Law Society Gazette. Available at: < https://www.lawgazette.co.uk/practice-points/why-joint-enterprise-isunfair-and-needs-changing/5045748.article> Accessed 5 Nov. 2018

Williams, P. and Clarke, B. (2016). Are joint enterprise convictions racially motivated?. MMU, [online] p.1. Available at: <https://www2.mmu.ac.uk/news-and-events/news/story/?id=4088> Accessed 21 November 2018

$\underline{\text { Websites }}$

BBC News, 'Joint Enterprise Law wrongly interpreted for 30 years, Supreme Court rules’ (UK, $18^{\text {th }}$ February 2016) <https://www.bbc.co.uk/news/uk-35598896 $>$ accessed on 24th October 2018 
'Unsafe', Cambridge Dictionary <https://dictionary.cambridge.org/dictionary/english/unsafe>

Other Media

Common. (2014). [film] Directed by D. Blair. UK: BBC. 